\title{
Effects of islet amyloid polypeptide on hepatic insulin resistance and glucose production in the isolated perfused rat liver
}

\author{
M. Roden, K. Liener, C. Fürnsinn, P. Nowotny, U.Hollenstein, H. Vierhapper and W. WaldhäusI \\ $\mathrm{I}^{\text {st }}$ Medical Department, Division of Clinical Endocrinology and Diabetology, University of Vienna, Austria
}

\begin{abstract}
Summary. The impact of (pancreatic) islet amyloid polypeptide on glucose metabolism and insulin sensitivity was examined in isolated rat livers perfused in a non-recirculating system. Continuous infusion of $10^{-7} \mathrm{~mol} / 1$ islet amyloid polypeptide affected neither basal nor glucagon $\left(10^{-9} \mathrm{~mol} / \mathrm{l}\right)$ stimulated glucose output by livers from fed rats, but it did increase the hepatic cyclic AMP release within $44 \mathrm{~min}$ $(7.91 \pm 12.07$ vs control: $0.07 \pm 0.03 \mathrm{pmol} \cdot 100 \mathrm{~g}$ body weight $\left.{ }^{-1}\right)$. The effect of the peptide on the ability of insulin to inhibit glucagon-induced hepatic glycogenolysis was measured in three experimental groups $(n=6)$. As expected glucagon $\left(7 \times 10^{-11} \mathrm{~mol} / \mathrm{l}\right)$ increased integral hepatic glucose release within $84 \mathrm{~min} \quad(763.4 \pm 161.7$ vs $-25.7 \pm 73.2$ $\mu \mathrm{mol} \cdot 100 \mathrm{~g} \mathrm{body}$ weight $^{-1}$ in the control group, $p<0.001$ ), while insulin $(100 \mathrm{mU} / \mathrm{l})$ decreased the glucagon-stimulated glucose production $(395.2 \pm 180.0 \mu \mathrm{mol} \cdot 100 \mathrm{~g}$ body werght ${ }^{-1}, p<0.01$ ). Simultaneous infusion of $10^{-7} \mathrm{~mol} / \mathrm{l}$ islet
\end{abstract}

amyloid polypeptide however, was not able to reverse insulin-dependent inhibition of glucagon-stimulated hepatic glucose output $\left(370.0 \pm 102.5 \mu \mathrm{mol} \cdot 100 \mathrm{~g}\right.$ body weight ${ }^{-1}$, NS) or to enhance lactate-induced gluconeogenesis of livers from $24 \mathrm{~h}$ fasted rats $(n=8)$. The glucose production stimulated by $10^{-9} \mathrm{~mol} / \mathrm{l}$ glucagon was slightly greater in islet amyloid polypeptide-pre-treated livers than in a control group without addition of islet amyloid polypeptide (5 min: $3.60 \pm 3.36 \mathrm{vs} 1.67 \pm 1.28 \mu \mathrm{mol} \cdot \mathrm{min}^{-1} \cdot 100 \mathrm{~g}$ body weight ${ }^{-1}$ ). These results suggest that islet amyloid polypeptide neither directly affects hepatic glycogenolysis nor causes insulin resistance to hormone-sensitive glucose production, but may increase the size of the hepatic glycogen pool by enhancing gluconeogenesis.

Key words: Isolated liver perfusion, insulin resistance, islet amyloid polypeptide.
Peripheral insulin resistance and increase in hepatic glucose production are characteristic features in the pathogenesis of Type 2 (non-insulin-dependent) diabetes mellitus $[1,2]$. Recently, a 37 amino acid polypeptide, islet amyloid polypeptide, IAPP [3], or diabetes associated peptide, DAP [4], has been purified from amyloid deposits in the pancreas of diabetic humans and cats as well as from human insulinoma tissues [3-5]. IAPP was found to be co-localized and co-secreted with insulin by pancreatic Beta cells [6,7] and was shown to be present in the peripheral blood of Type 2 diabetic patients [8].

Some evidence has been provided for the potential role of the peptide in the development of insulin resistance and disturbance of carbohydrate metabolism. IAPP inhibits insulin-stimulated glucose uptake and glycogen formation in vitro in isolated skeletal muscle and cultured myocytes $[9,10]$. Moreover, IAPP antagonizes the ability of insulin to stimulate peripheral glucose disposal in hyperinsulinaemic euglycaemic clamp studies in vivo in rats and dogs $[11,12]$. Nevertheless, conflicting re- sults on the impact of the peptide on hepatic carbohydrate metabolism have been reported. IAPP has been shown to accelerate glucose incorporation into glycogen and to stimulate gluconeogenesis from lactate in vitro in HepG2 cells [13]. On the other hand, Young et al. [14] found decreased glycogen and glucose-6-phosphate contents in rat livers following IAPP infusion in vivo. To further elucidate these ambiguous findings on the metabolic action of IAPP, its potential effects on hepatic insulin resistance and glucose metabolism were studied in the model of the isolated perfused rat liver.

\section{Materials and methods}

Male Sprague-Dawley rats $(254 \pm 17 \mathrm{~g}$; Him: OFA/SPF, Tierforschungsinstitut, Himberg, Austria) were subjected to a $12 \mathrm{~h}$ daynight cycle for at least 1 week before the experiment and were allowed free access to standard chow and tap water. 


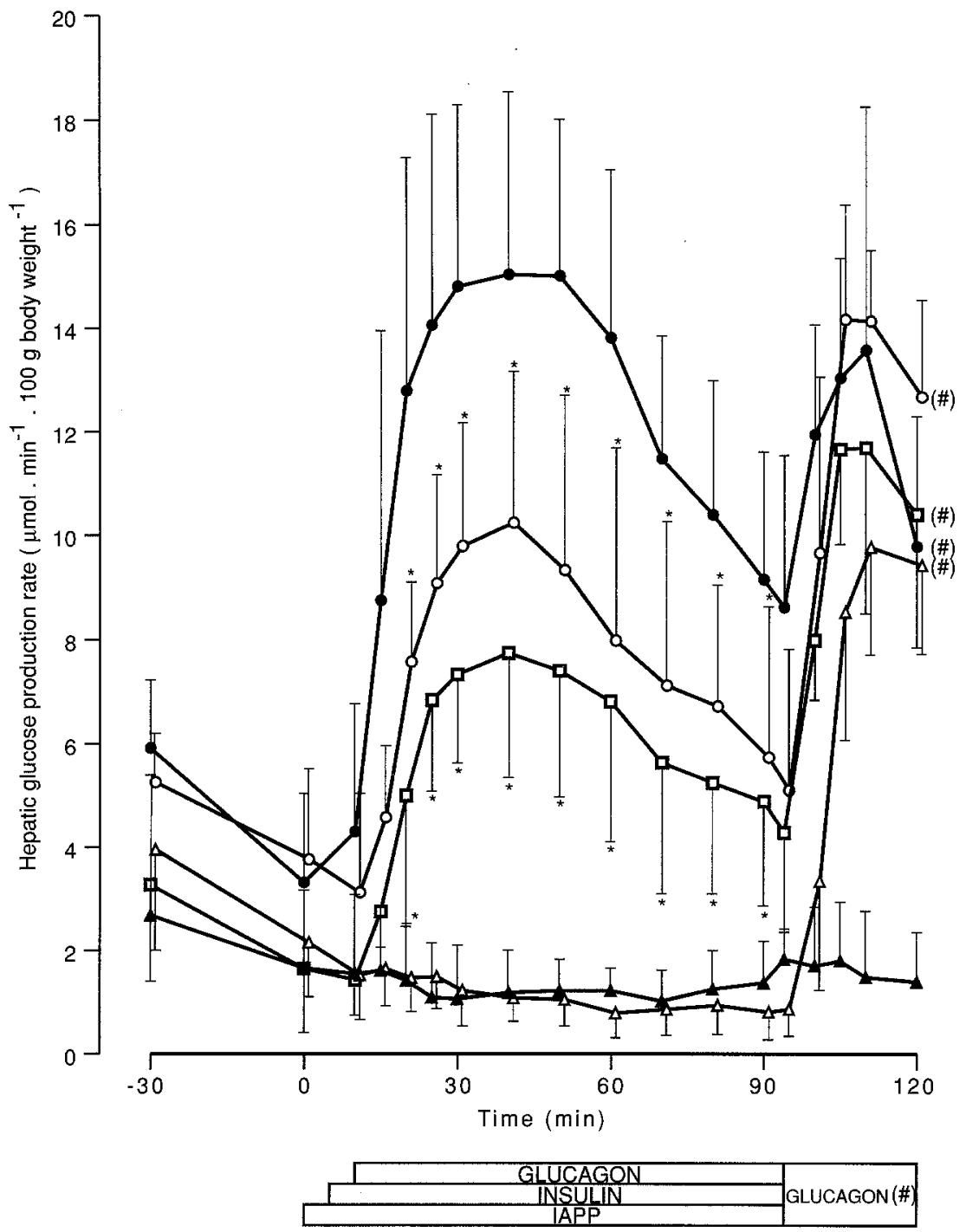

Fig.1. Effect of islet amyloid polypeptide (IAPP, $10^{-7} \mathrm{~mol} / \mathrm{l}$ ) on glycogenolysis in perfused livers from fed rats. Continuous infusions of peptides were started at $0 \mathrm{~min}\left(10^{-7} \mathrm{~mol} / 1 \mathrm{IAPP}\right)$, at $5 \mathrm{~min}$ $(100 \mathrm{mU} / \mathrm{l}$ insulin $)$ and at $10 \mathrm{~min}\left(7 \times 10^{-11} \mathrm{~mol} / 1\right.$ glucagon), respectively, and lasted up to $94 \mathrm{~min}$ (- glucagon, $0-$ o glucagon + insulin, $\square-\square$ glucagon + insulin + IAPP, $\triangle \triangle$ IAPP alone, $\triangle$ infusion of Krebs-Ringer buffer serving as control). From $95 \mathrm{~min}$ to $120 \mathrm{~min}$ $10^{-9} \mathrm{~mol} / \mathrm{l}$ glucagon was given in all, but control experiments $(\mathbf{A})$ to empty the residual glycogen pool. Data are presented as mean \pm SD of six experiments in each group. $* p<0.01$ vs glucagon infusion
Preparation and perfusion of rat livers was performed as described previously [15]. Briefly, the isolated liver was placed in a humidified chamber and perfused (flow rate: $6.9 \pm 0.1 \mathrm{ml} / \mathrm{min}$ ) in a nonrecirculating system with oxygenated Krebs-Ringer buffer with dialysed, aged human erythrocytes at $\mathrm{pH}$ equal to 7.4 and $37^{\circ} \mathrm{C}$ and a haematocrit of approximately $20 \%$. Additionally, the medium contained $2 \%$ dialysed bovine serum albumin (BSA, fraction V; Boehringer-Mannheim, Mannheim, FRG). IAPP and hormones were dissolved in Krebs-Ringer buffer containing $2 \%$ dialysed BSA to prevent non-specific binding to plastic surfaces and were admixed to the perfusate at a constant rate of $0.2 \mathrm{ml} / \mathrm{min}$ (Perfusor V, Braun, Melsungen AG, Melsungen, FRG) with a needle that was inserted into the portal cannula.

Carboxyamidated rat IAPP was purchased from Peninsula Laboratory (Catalog-No.7323, Belmont, Calif., USA). Its biological activity has been previously tested by Young et al. [14], who observed significant inhibition of ${ }^{14} \mathrm{C}$-glycogen accumulation in isolated rat soleus muscle by this preparation of IAPP. Human insulin (Actrapid $\mathrm{MC}$ ) and glucagon were obtained from Novo-Nordisk (Copenhagen, Denmark).

\section{Study of hepatic glycogenolysis}

The livers were isolated from fed rats at 08.00 hours, while they were still full of glycogen [15], and perfused with medium containing $5 \mathrm{mmol} / 1 \mathrm{D}(+)$-glucose. After $60 \mathrm{~min}$ of equilibration IAPP and/or hormones were added and infused continuously during $94 \mathrm{~min}$. Subsequently, $10^{-9} \mathrm{~mol} / 1$ glucagon was given to ensure the liver's intact hormonal responsiveness at the end of the perfusion and to empty the residual hepatic glycogen pool.

\section{Study of hepatic gluconeogenesis}

The livers were depleted of glycogen by fasting the rats for $24 \mathrm{~h}$ prior to the experiments [16]. Subsequently, livers were isolated and perfused with gluconeogenic precursors $(10 \mathrm{mmol} / \mathrm{L} \mathrm{L}$-lactate, $1 \mathrm{mmol} / 1$ pyruvate, $1 \mathrm{mmol} / \mathrm{L}$ L-alanine) and $0.5 \mathrm{mmol} / \mathrm{l} \mathrm{Na}$-oleate instead of $\mathrm{D}(+)$-glucose [16]. In addition, IAPP or Krebs-Ringer buffer were continuously infused following a $30 \mathrm{~min}$ equilibration period. Thereafter, $10^{-9} \mathrm{~mol} / \mathrm{l}$ glucagon was added to maximally stimulate hepatic glycogenolysis and to estimate the amount of glycogen formed during the preceding period.

The concentrations of glucose and lactate were assayed by the hexokinase- and lactate dehydrogenase-method using commercially available kits (Boehringer-Mannheim). For cyclic AMP determination samples were applied to $\mathrm{C} 8$ columns (Analytichem International, Harbor City, Calif., USA) pre-treated with successive application of $2 \mathrm{ml}$ methanol and $10 \mathrm{ml}$ distilled water. After evaporation under a stream of nitrogen at $37^{\circ} \mathrm{C}$ and lyophilization, the eluated samples were reconstituted in assay buffer. Following acetylation with acetic anhydride and triethylamine $(1: 2)$ 
the samples were measured by RIA (Amersham, Amersham, UK).

Hepatic production rates of glucose and lactate were calculated from the transhepatic concentration differences times flow rate and related to rat body weight (bw). Integral release of glucose or cyclic AMP by the liver was assessed within a defined time period from the area under the time-curve of glucose or cyclic AMP production rates, which were corrected for basal glucose or cyclic AMP output at time point: $0 \mathrm{~min}$, using the trapezoidal rule.

\section{Statistical analysis}

Unless stated otherwise data are presented as mean \pm SD. Statistical evaluation was performed by the two-tailed Student's $t$-test or by analysis of variance (ANOVA) followed by Duncan's multiple range test as appropriate [17].

\section{Results}

During continuous infusion of $10^{-7} \mathrm{~mol} / \mathrm{l}$ IAPP glucose production rates of livers from fed rats slightly decreased from $2.15 \pm 1.07$ prior to IAPP administration to a minimum of $0.78 \pm 0.47 \mu \mathrm{mol} \cdot \mathrm{min}^{-1} .100 \mathrm{~g} \mathrm{bw}^{-1}$ at $60 \mathrm{~min}$ (Fig.1). The time course of glucose production rates as well as the corresponding area under the curve $\left(-43.1 \pm 39.1 \mu \mathrm{mol} \cdot 100 \mathrm{~g} \mathrm{bw}^{-1}\right)$ were not different from that of control experiments without added IAPP $\left(-25.7 \pm 73.2 \mu \mathrm{mol} \cdot 100 \mathrm{~g} \mathrm{bw}^{-1}\right)$. However, subsequent infusion of $10^{-9} \mathrm{~mol} / \mathrm{l}$ glucagon rapidly increased hepatic glucose production reaching the peak $(9.75 \pm 2.06 \mu \mathrm{mol}$ . $\mathrm{min}^{-1} .100 \mathrm{~g} \mathrm{bw}^{-1}$ ) at $15 \mathrm{~min}$ demonstrating considerable residual hepatic glycogen content (Fig.1).

Glucagon-induced glycogenolysis in livers from fed rats was not affected by IAPP-pre-treatment as compared to control experiments (maximal glucose output after $70 \mathrm{~min}: 13.38 \pm 1.55$ vs $12.84 \pm 3.05 \mu \mathrm{mol} \cdot \mathrm{min}^{-1} \cdot 100 \mathrm{~g}$ $\mathrm{bw}^{-1}$, NS; Fig.2). Interestingly, during infusion of IAPP the hepatic release of cyclic AMP within 44 min was increased ( $7.91 \pm 12.07$ vs control: $0.07 \pm 0.03$ pmol $\cdot 100 \mathrm{~g}$ $\left.b w^{-1}\right)$.

A further series of experiments tested the influence of IAPP on insulin sensitivity of glucagon-stimulated hepatic glucose production by perfused livers from fed rats (Fig. 1). Infusion of $7 \times 10^{-11} \mathrm{~mol} / 1$ glucagon resulted in the expected enhancement of glucose output reaching its maximum after $40 \mathrm{~min}$ (Table 1 ). Thereafter, glucose production gradually fell and the residual glycogen pool was emptied by subsequent infusion of $10^{-9} \mathrm{~mol} / \mathrm{l}$ glucagon (second peak value: $13.55 \pm 4.67 \mu \mathrm{mol} \cdot \mathrm{min}^{-1} \cdot 100 \mathrm{~g}$ $\left.\mathrm{bw}^{-1}\right)$. Adding $100 \mathrm{mU} / \mathrm{l}$ insulin to the perfusate decreased hepatic glucose production by $32 \%$ after $40 \mathrm{~min}$ $(p<0.01)$. In the presence of $10^{-7} \mathrm{~mol} / 1 \mathrm{IAPP}$ hepatic glucose output decreased further as compared to the infusion of glucagon alone $(p<0.01)$. Glucagon-stimulated incremental glucose release was inhibited by $48 \%$ in the presence of insulin ( $p<0.01$ vs control) and was not reversed by IAPP (NS vs infusion of glucagon + insulin; Table 1).

Potential effects of IAPP on hepatic gluconeogenesis were studied in glycogen-free livers from $24 \mathrm{~h}$ fasted rats

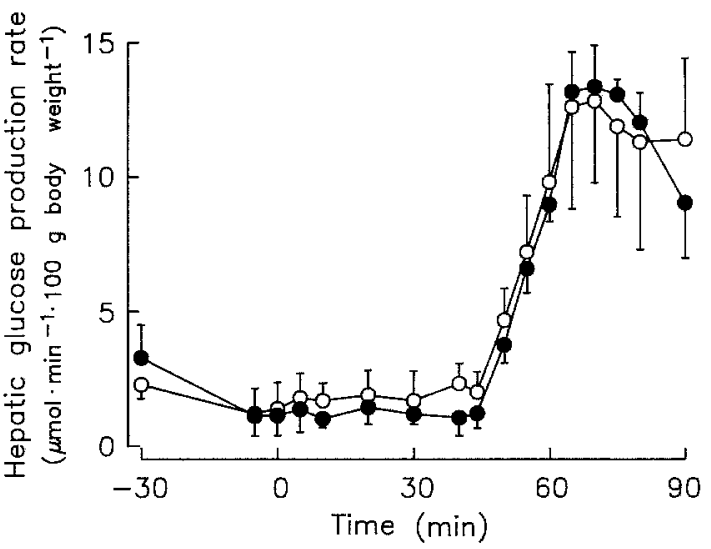

Fig. 2. Hepatic glucose production of perfused livers obtained from fed rats induced by infusion $(45-90 \mathrm{~min})$ of $10^{-9} \mathrm{~mol} / \mathrm{l}$ glucagon following infusion $(0-40 \mathrm{~min})$ of $10^{-7} \mathrm{~mol} / 1$ islet amyloid polypeptide $(\bullet)$ or Krebs-Ringer buffer (control, $\mathrm{O}-\mathrm{O}$ ). Data are given as mean \pm SD of three experiments in both groups

perfused with glucose-free Krebs-Ringer buffer containing L-lactate, pyruvate and alanine as gluconeogenic precursors. Lactate-dependent hepatic glucose production rates were not different in the presence of $10^{-7} \mathrm{~mol} / \mathrm{l}$ IAPP (0-40 min) and in its absence (Fig. 3). The corresponding lactate uptake rate at $40 \mathrm{~min}$ was gradually increased in IAPP-treated livers compared to untreated livers $\left(4.7 \pm 5.4 \mathrm{vs} 2.2 \pm 1.5 \mathrm{mmol} \cdot \mathrm{min}^{-1} \cdot 100 \mathrm{~g} \mathrm{bw}^{-1}\right.$, NS). However, in IAPP-pre-treated livers lactate-induced glucose production rapidly rose more than two-fold within $5 \mathrm{~min}$ from $1.66 \pm 1.19$ to $3.60 \pm 3.66 \mu \mathrm{mol} \cdot \mathrm{min}^{-1} \cdot 100 \mathrm{~g}$ $\mathrm{bw}^{-1}$ following exposure to $10^{-9} \mathrm{~mol} / \mathrm{l}$ glucagon, whereas glucose output was not altered in untreated livers (at 0 min: $1.44 \pm 0.97$ and at $5 \mathrm{~min}: 1.67 \pm 1.28 \mu \mathrm{mol}$. $\min ^{-1} \cdot 100 \mathrm{~g} \mathrm{bw}^{-1}$, NS; Fig. 4). The incremental glucagondependent glucose release was slightly, but not significantly enhanced in perfusates of IAPP-treated livers and remained higher until the end of the glucagon infusion at $75 \mathrm{~min}$ (Fig.4). Following pre-treatment of the liver with $10^{-10} \mathrm{~mol} / \mathrm{l}$ IAPP $(n=3)$ there was a statistically significant elevation of glucagon-induced glucose production after $15 \mathrm{~min} \quad\left(+0.97 \pm 0.39 \mu \mathrm{mol} \cdot \mathrm{min}^{-1} \cdot 100 \mathrm{~g} \mathrm{bw}^{-1}\right.$, $p<0.01$ ).

Table 1. Maximal glucose production rates (at $40 \mathrm{~min}$ ) and integral hepatic glucose release as calculated from the area under the time curves of Figure 1 (10 min-94 min, corrected for basal glucose output). Data are given as mean \pm SD of six experiments in each group

\begin{tabular}{lll}
\hline & $\begin{array}{l}\text { Maximal glucose } \\
\text { production rate } \\
\left(\mu \mathrm{mol} \cdot \mathrm{min}^{-1} \cdot 100 \mathrm{~g} \mathrm{bw}^{-1}\right)\end{array}$ & $\begin{array}{l}\text { Integral hepatic } \\
\text { glucose release } \\
\left(\mu \mathrm{mol} \cdot 100 \mathrm{~g} \mathrm{bw}^{-1}\right)\end{array}$ \\
\hline $\begin{array}{l}\text { Glucagon } \\
(=\text { control })\end{array}$ & $15.02 \pm 3.50$ & $763.4 \pm 161.7$ \\
$\begin{array}{l}\text { Glucagon } \\
+ \text { insulin }\end{array}$ & $10.23 \pm 2.91^{\mathrm{b}}$ & $395.2 \pm 180.0^{\mathrm{a}}$ \\
$\begin{array}{l}\text { Glucagon } \\
+ \text { insulin } \\
+ \text { IAPP }\end{array}$ & $7.73 \pm 2.38^{\mathrm{b}}$ & $370.0 \pm 102.5^{\mathrm{b}}$ \\
\hline
\end{tabular}

${ }^{\mathrm{a}} p<0.05,{ }^{\mathrm{b}} p<0.01$ vs control; bw, body weight; IAPP, islet amyloid polypeptide 


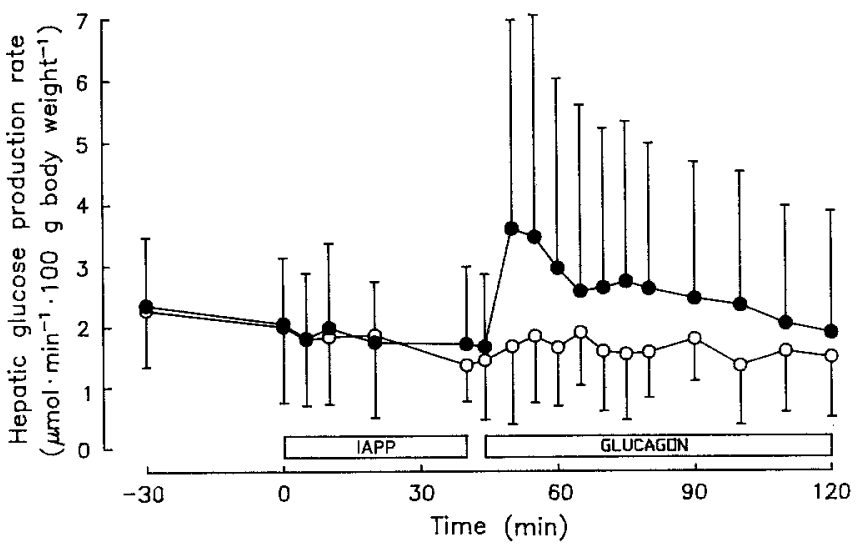

Fig. 3. Effect of islet amyloid polypeptide (IAPP, $10^{-7} \mathrm{~mol} / \mathrm{l}$ ) on glucose production and glycogen synthesis in livers from $24 \mathrm{~h}$ fasted rats. Following infusion of IAPP $(\bullet)$ ) or Krebs-Ringer buffer (control, $0-0$ ) from $0 \mathrm{~min}$ to $40 \mathrm{~min} 10^{-9} \mathrm{~mol} / \mathrm{l}$ glucagon was admixed from $45 \mathrm{~min}$ to $120 \mathrm{~min}$ for estimation of the hepatic glycogen stores by measuring glucagon-sensitive glucose release. Data are presented as mean \pm SD of eight experiments in both groups

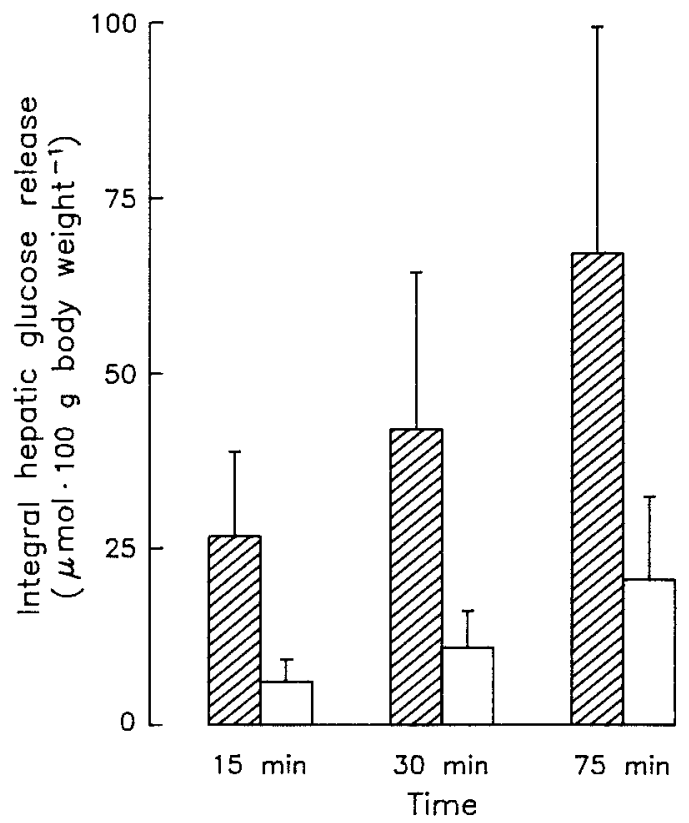

Fig.4. Cumulative hepatic glucose release, corrected for basal hepatic glucose output, estimated within $15 \mathrm{~min}, 30 \mathrm{~min}$ and $75 \mathrm{~min}$ after addition of glucagon in the experiments of Figure 3 (islet amyloid polypeptide: hatched bars, control: empty bars). Data are given as mean \pm SEM of eight experiments in both groups

\section{Discussion}

The results indicate that IAPP neither affects basal hepatic glucose production nor counteracts insulin-sensitive glucagon triggered hepatic glycogenolysis. IAPP increases, however, the glucagon-sensitive glycogen pool in the rat liver possibly due to promotion of hepatic gluconeogenesis.

Amidated IAPP was infused at a concentration of $10^{-7} \mathrm{~mol} / \mathrm{l}$, which is close to the half-maximal-inhibition $\left(\mathrm{IC}_{50}\right)$ of its binding to receptors for calcitonin generelated peptide on rat liver plasma membranes $(3 \times$ $\left.10^{-7} \mathrm{~mol} / \mathrm{l}\right)[18]$, but considerably higher than concentrations of the peptide circulating in human plasma (approximately $\left.10^{-11} \mathrm{~mol} / \mathrm{l}\right)$ [8].

The observation of the present study that hepatic glycogenolysis from perfused livers of fed rats is not stimulated by IAPP is in agreement with unpublished data in a perfused rat liver system mentioned by Sowa et al. [11]. Similarly, infusion of $5 \mathrm{nmol} \cdot \mathrm{kg}^{-1} \cdot \mathrm{min}^{-1}$ IAPP in vivo in a hyperinsulinaemic euglycaemic clamp study using $18 \mathrm{~h}$ fasted rats [14], when the liver becomes the only source of glucose entering the circulation [16], did not change the overall rate of glucose appearance despite a rise in blood glucose levels. These authors explained the observed increase by IAPP in blood glucose concentrations by an extrahepatic block of peripheral glucose disposal, since 2-deoxy-, but not 3-O-methyl-D-glucose uptake was inhibited by 10 and $100 \mathrm{nmol} / 1 \mathrm{IAPP}$ in isolated rat soleus muscle [14]. The observation that $0.1 \mathrm{nmol} / \mathrm{l}$ IAPP accelerates the breakdown of previously labelled glycogen in HepG2 cells [13] could not be confirmed by our experimental approach.

Despite its inability to directly affect basal hepatic glycogenolysis in fed rats IAPP is still able to impair hepatic insulin sensitivity by its induction of insulin resistance in vivo and in vitro in isolated skeletal muscle [9-12]. However, IAPP did not reverse insulin-dependent inhibition of glucagon-stimulated hepatic glucose production in the perfused rat liver. This observation is in contrast to the findings of Molina et al. [12], who reported that IAPP antagonized insulin-dependent inhibition of hepatic glucose output during a hyperinsulinaemic glucose clamp study in non-diabetic rats. The fact that these results were obtained in vivo and not in an isolated liver suggests that the observed rise in hepatic glucose output during IAPP exposure had been caused by increased provision of gluconeogenic precursors in the course of decreased glucose uptake and metabolism by skeletal muscle.

IAPP dit not affect glucose release from livers of $24 \mathrm{~h}$ fasted rats perfused with a glucose-free, lactate-containing medium, whereas in livers exposed to IAPP glucagon induced stimulation of hepatic glycogenolysis. This effect was more pronounced in the presence of $10^{-10} \mathrm{~mol} / \mathrm{l} \mathrm{IAPP}$ and may relate to increased hepatic glycogen formation from gluconeogenic precursors (L-lactate, pyruvate and alanine). Similarly, an $80 \%$ rise by $10 \mathrm{pmol} / 1$ IAPP in the rate of hepatic gluconeogenesis from lactate has been reported in HepG2 cells [13], which is, however, in contrast to an in vivo study demonstrating a reduction in liver glycogen following IAPP exposure [14]. On the other hand, the IAPP-dependent elevation of glucagon-induced glycogenolysis in livers from fasted rats could be explained by promotion of the glycogenolytic action of glucagon. In this context, it is of interest that binding of IAPP to hepatic receptors for calcitonin gene-related peptide activates adenylate cyclase [18], which catalyzes the synthesis of cyclic AMP, which in turn serves as second messenger of glucagon action $[19,20]$. Although the present study reports evidence for increased cyclic AMP production during IAPP infusion, IAPP did not increase glucagon-dependent glycogenolysis in livers from fed rats. It should be noted that recently Stephens et al. [21] demonstrated that 
IAPP rather binds to receptors located at non-parenchymal cells of rat liver.

In conclusion, IAPP does not affect hepatic glycogenolysis, but increases the production of cyclic AMP and may stimulate hepatic gluconeogenesis and glycogen synthesis directly and/or by modulating the glucagon action on the liver.

Acknowledgements. This study was supported in part by a grant of the 'Fonds zur Förderung der wissenschaftlichen Forschung Österreich' No.P 8159 - Med.

\section{References}

1. DeFronzo RA (1987) Lilly lecture 1987: The triumvirate: $\beta$-cell, muscle, liver: a collusion responsible for NIDDM. Diabetes 37: 667-687

2. Olefsky JM (1980) Insulin resistance and insulin action. An in vitro and in vivo perspective. Diabetes 30:148-162

3. Westermark P, Wernstedt C, Wilander E, Hayden DW, O'Brien TD, Johnson KH (1987) Amyloid fibrils in human insulinoma and islets of Langerhans of the diabetic cat are derived from a neuropeptide-like protein also present in normal islet cells. Proc Natl Acad Sci USA 84: 3881-3885

4. Cooper GJS, Willis AC, Clark A, Turner RC, Sim RB, Reid KBM (1987) Purification and characterization of a peptide from amyloid-rich pancreases of type 2 diabetic patients. Proc Natl Acad Sci USA 84: 8628-8632

5. Johnson KH, O'Brien TD, Hayden DW et al. (1988) Immunolocalization of islet amyloid polypeptide (IAPP) in pancreatic beta cells by means of peroxidase-antiperoxidase (PAP) and protein A-gold techniques. Am J Pathol 130: 1-8

6. Leffert JD, Newgard CB, Okamoto H, Milburn JL, Luskey KL (1989) Rat amylin cloning and tissue-specific expression in pancreatic islets. Proc Natl Acad Sci USA 86: 3127-3130

7. Kahn SE, D'Alessio DA, Schwartz MW et al. (1990) Evidence of cosecretion of islet amyloid polypeptide and insulin by beta-cells. Diabetes 39: 634-638

8. Nakazato M, Asai J, Kanagawa K, Sakakibara S, Matsukura S, Matsuo H (1989) Establishment of radioimmunoassay for human islet amyloid polypeptide and its tissue content and plasma concentration. Biochem Biophys Res Commun 164: 394-399

9. Leighton B, Cooper GJS (1988) Pancreatic amylin and calcitonin-gene related peptide cause resistance to insulin in skeletal muscle in vitro. Nature (London) 335: 632-635
10. Cooper GJS, Leighton B, Dimitriadis GD et al. (1988) Amylin found in amyloid deposits in human type 2 diabetes mellitus may be a hormone that regulates glycogen metabolism in skeletal muscle. Proc Natl Acad Sci USA 85: 7763-7766

11. Sowa R, Sanke T, Hirayama J et al. (1990) Islet amyloid polypeptide amide causes peripheral insulin resistance in vivo in dogs. Diabetologia 33: 118-120

12. Molina JM, Cooper GJS, Leighton B, Olefsky JM (1990) Induction of insulin resistance in vivo by amylin and calcitonin gene-related peptide. Diabetes 39:260-265

13. Ciaraldi TP, Cooper GJS, Stolpe M (1990) In vitro effects of amylin on carbohydrate metabolism. Diabetes 39: 149A (Abstract)

14. Young DA, Deems RO, Deacon RW, McIntosh RH, Foley JE (1990) Effects of amylin on glucose metabolism and glycogenolysis in vivo and in vitro. Am J Physiol:E457-E461

15. Komjati M, Bratusch-Marrain P, Waldhäusl W (1986) Superior efficacy of pulsatile versus continuous hormone exposure on hepatic glucose production in vitro. Endocrinology 118: 312-319

16. Exton JH, Park CR (1967) Control of gluconeogenesis in liver. I. General features of gluconeogenesis in the perfused livers of rats. J Biol Chem 242: 2622-2636

17. SAS User's Guide (1982) Statistics. SAS Institute, Cary

18. Morishita T, Yamaguchi A, Fujita T, Chiba T (1990) Activation of adenylate cyclase by islet amyloid polypeptide with $\mathrm{COOH}$ terminal amide via calcitonin gene-related peptide receptors on rat liver plasma membranes. Diabetes 39: 875-877

19. Exton JH, Lewis SB, Ho RJ, Robinson GA, Park CR (1971) The role of cyclic AMP in the interaction of glucagon and insulin in the control of liver metabolism. Ann NY Acad Sci 185: 85-100

20. Sutherland EW, Rall TW (1958) Fractionation and characterization of a cyclic adenine ribonucleotide formed by tissue particles. J Biol Chem 232: 1077-1091

21. Stephens TW, Heath WF, Hermeling RN (1991) Presence of liver CGRP/Amylin receptors in only nonparenchymal cells and absence of direct regulation of rat liver glucose metabolism by CGRP/Amylin. Diabetes 40:395-400

Received: 20 June 1991

and in revised form: 17 October 1991

Dr. M. Roden

Division of Clinical Endocrinology and Diabetology

1 st Department of Medicine

Lazarettgasse 14

A-1090 Vienna

Austria 